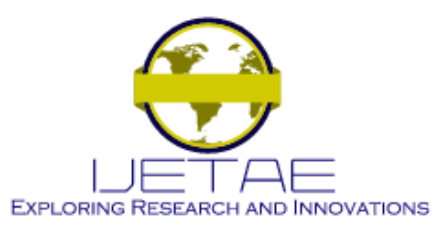

International Journal of Emerging Technology and Advanced Engineering

Website: www.ijetae.com (ISSN 2250-2459, ISO 9001:2008 Certified Journal, Volume 11, Issue 02, February 2021)

Manuscript Received: 15 Dec 2020, Revised: 24 Jan 2021, Accepted: 18 Feb 2021

CrossRef DOI: 10.46338/ijetae0221_02

\title{
Theoretical Study of a Bifacial Silicon Solar Cell Front Side Illuminated: Magnetic Field Effect on the Recombination Velocities Inducing the Short Circuit and Limiting the Open Circuit
}

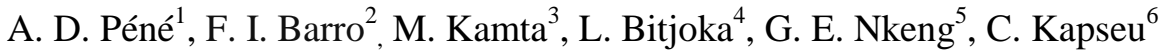 \\ ${ }^{1}$ University Institute of Technology, University of Ngaoundere, Cameroon \\ ${ }^{1,2}$ Laboratory of Semiconductors and Solar Energy, Physics Department, Faculty of Science and Technology, University Cheikh \\ Anta Diop, Dakar, Senegal \\ 1, 3, 4 Laboratory of Energy, Signal, Images, Automatic (LESIA), Department of Electrical Engineering Energetic and Automatic, \\ National Advanced School of Agro-Industrial Sciences, University of Ngaoundere, Cameroon \\ ${ }^{5}$ National School of Public Works of Yaounde, Cameroon \\ ${ }^{6}$ RESH Laboratory, Department of Process Engineering National Advanced School of Agro-Industrial Sciences, University of \\ Ngaoundere, Cameroon
}

\begin{abstract}
The aim of this work is to present a study of the recombination velocities at the junction initiating the shortcircuit (Sfsc) and limiting the open circuit (Sfoc) of a silicon solar cell under magnetic field in the static regime. From the continuity equation, the density of minority charge carriers in the base, the photocurrent density, and the phototension are determined. The study of the photocurrent density and the phototension, as a function of the junction recombination velocity, makes it possible to determine the recombination velocities at the junction initiating the short-circuit and limiting the open circuit respectively. From the profile of the variation of the photocurrent density and of the phototension as a function of the junction recombination velocity, a technique for determining the junction recombination velocities initiating the short circuit situation and limiting the open circuit is presented.
\end{abstract}

Keywords- bifacial solar cell, junction recombination velocities, short-circuit, open circuit

\section{INTRODUCTION}

Increasing the performance of solar cells is the key element of researchers around the world. In fact, the structure of solar cells has been improved, moving from conventional cells [1-4] to bifacial cells which can be illuminated from both the front and rear sides simultaneously [5-11]. The main advantage of these improvements is to obtain a better conversion efficiency [12-15].
In this article, the aim is to propose a technique for determining junction recombination speeds initiating the short-circuit and limiting the open circuit of a bifacial solar cell illuminated by multispectral light $[3,4,8]$ and maintained in steady state with an external magnetic field. We first present a theoretical study of the bifacial solar cell under the effect of the magnetic field [8, 16, 17]. Solving the continuity equation makes it possible to determine the expression of the density of the minority charge carriers and to deduce the photocurrent density and the phototension which make it possible to introduce the concept of the recombination speeds at the junction initiating the short- circuit and limiting the open circuit

\section{THEORETICAL STUDY}

We consider $\mathrm{a} \mathrm{n}^{+} \mathrm{pp}^{+}$polycrystalline silicon solar cell [8, $18,19]$ presented on figure 1 :

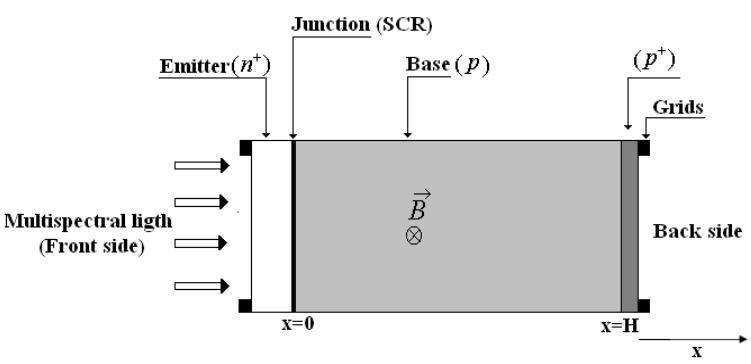

Figure $1: \mathbf{n}^{+} \mathbf{p p}^{+}$polycrystalline silicon solar cell structure 


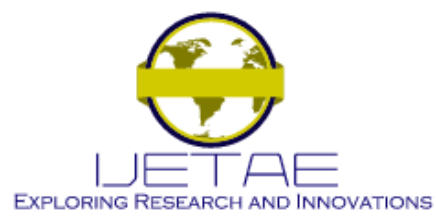

\section{International Journal of Emerging Technology and Advanced Engineering Website: www.ijetae.com (ISSN 2250-2459, ISO 9001:2008 Certified Journal, Volume 11, Issue 02, February 2021)}

\section{A. Excess minority carrier's density in the base}

The continuity equation relative to excess minority carriers $\delta(\mathbf{x})$ in the base of the solar cell is given by:

$$
\frac{\partial^{2} \delta(x)}{\partial x}-\frac{\delta(x)}{L *^{2}}=-\frac{G(x)}{D *}
$$

$\mathrm{G}(\mathrm{x})$ is the carriers' generation rate under multispectral light at the depth $\mathrm{x}$ in the base; $\mathrm{G}(\mathrm{x})$ can be written as:

$$
G(x)=n \cdot \sum_{i=1}^{3} a_{i} \cdot \exp \left(-b_{i} \cdot x\right)
$$

$n$ indicates the illumination level ( $n=1$ in this study), $a_{i}$ and $b_{i}$ are coefficients tabulated from overall the AM 1,5 spectrum [20].

$D^{*}$ is the diffusion coefficient of excess minority carriers in the base of the bifacial cell in presence of magnetic field [8 21, 22]; it can be expressed as:

$$
D^{*}=\frac{D}{1+(\mu \cdot B)^{2}}
$$

In this expression, $\mathrm{D}$ is the diffusion constant without magnetic field and $\mu$ minority carriers' mobility.

$\mathrm{L}^{*}$ is the excess minority carriers' diffusion length in presence of magnetic field; we have:

$$
L^{*}=\sqrt{\frac{D}{1+(\mu \cdot B)^{2}} \cdot \tau}
$$

We $\tau$ is the excess minority carriers lifetime in the base of the solar cell.

The general solution of the equation (1) is given by :

$$
\delta(x)=A \cdot \cosh \left(\frac{x}{L^{*}}\right)+B \cdot \sinh \left(\frac{x}{L^{*}}\right)+\sum_{i=1}^{3} C_{i} \cdot \exp \left(-b_{i} \cdot x\right)
$$

with :

$$
C_{i}=-\frac{n \cdot a_{i} \cdot L *^{2}}{D *\left(b_{i}^{2} \cdot L *^{2}-1\right)}
$$

$\delta(\mathrm{x})$ is the excess minority carriers density in the base ; coefficients $\mathrm{A}$ and $\mathrm{B}$ can be calculated by use of the following boundary conditions :
- At the junction $(\mathrm{x}=0)$ :

$$
\left.D * \cdot \frac{\partial \delta(x)}{\partial x}\right|_{x=0}=\left.S f \cdot \delta(x)\right|_{x=0}
$$

- At the back side $(\mathrm{x}=\mathrm{H})$

$$
\left.D * \cdot \frac{\partial \delta(x)}{\partial x}\right|_{x=H}=-\left.S b \cdot \delta(x)\right|_{x=H}
$$

Parameters $\mathrm{Sf}$ and $\mathrm{Sb}$ are respectively the junction and back surface recombination velocities $[23,24]$.

\section{B. Photocurrent}

The photocurrent density is given by the following relation:

$$
J_{p h}=\left.q \cdot D \cdot \frac{\partial \delta(x)}{\partial x}\right|_{x=0}
$$

where $\mathrm{q}$ is the elementary charge.

\section{Photovoltage}

The photovoltage accross the junction is determinated by mean of Boltzmann's relation:

$$
V_{p h}=V_{T} \cdot \ln \left[\frac{\delta(0)}{n_{0}}+1\right]
$$

$V_{T}$ is the thermal voltage $\left(V_{T}=\frac{k \cdot T}{q}=26 \mathrm{mV}\right.$ at $\mathrm{T}=300 \mathrm{~K}), \quad \mathrm{n}_{0}$ is the equilibrium concentration : $n_{0}=\frac{n_{i}^{2}}{N_{B}}$

$n_{i}$ is the intrinsic carrier concentration, $N_{B}$ the base doping concentration and $\mathrm{k}$ the Boltzmann constant.

\section{RESUlTS AND DisCUSSIONS}

We present now the simulation results obtained from the theoretical expressions presented previously.

\section{A. Diffusion coefficient and diffusion length}

Figure 2 and 3 illustrate respectively the behavior of the diffusion coefficient and the diffusion length versus magnetic field. 


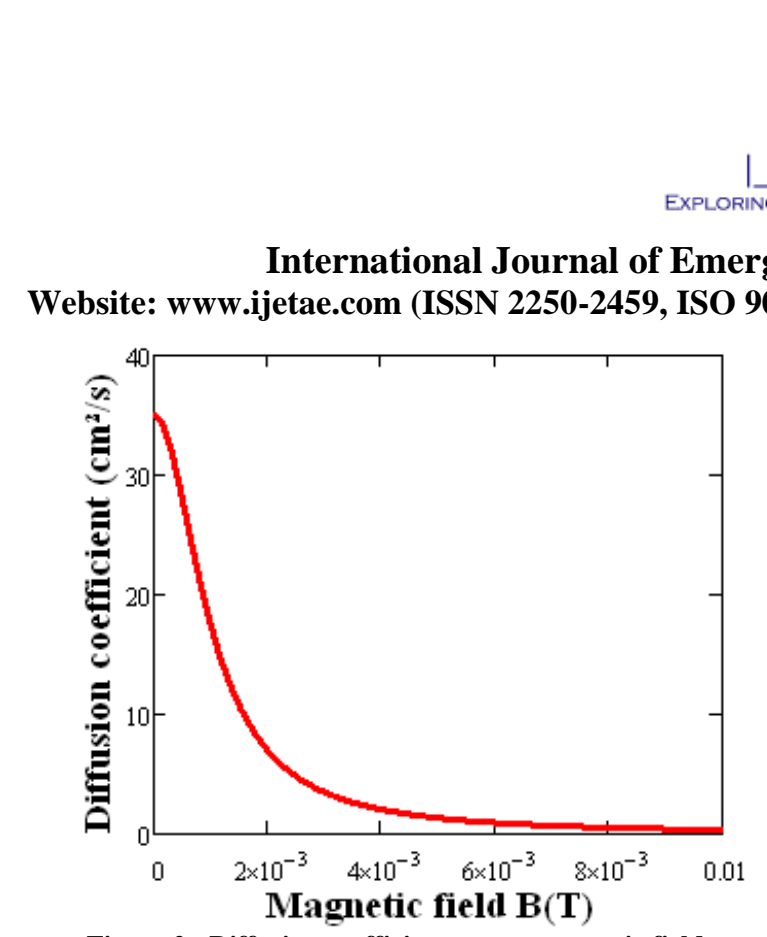

Figure 2 : Diffusion coefficient versus magnetic field

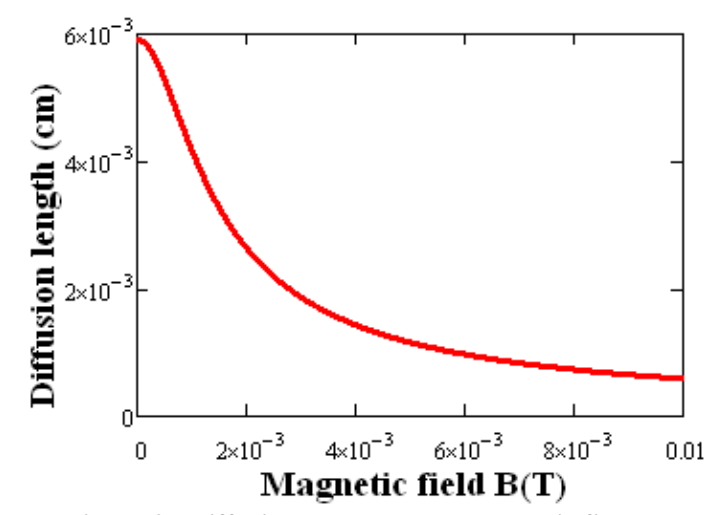

Figure 3 : Diffusion length versus magnetic field

There two figures show that both diffusion coefficient and diffusion length decrease with increasing magnetic field ; effectively, when the solar cell in under magnetic field effect, the excess minority carriers cannot go straight their diffusion path is incurvated so that the diffusion process though the base become more difficult.

\section{B. Excess minority carriers density}

We show of figure 4 the excess minority carriers density versus base depth for various magnetic fields.

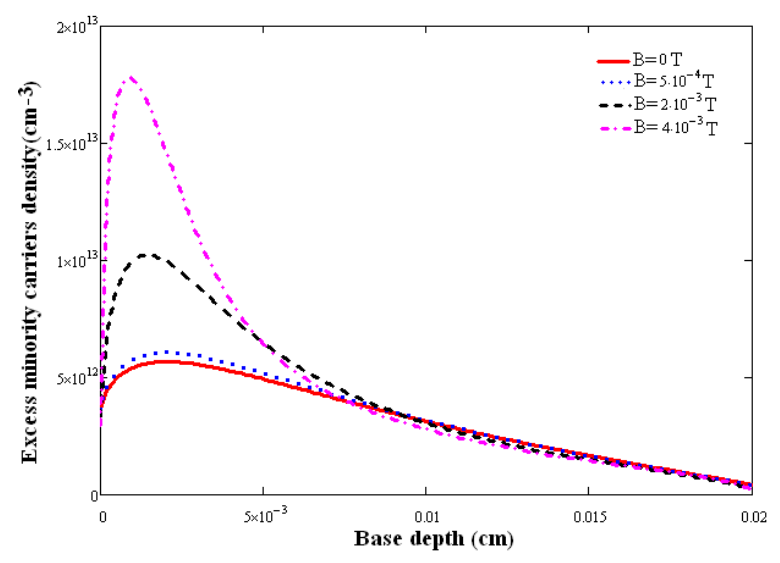

Figure 4: Excess minority carriers density versus base depth for various magnetic field $\left(D=26 \mathrm{~cm}^{2} / \mathrm{s}, \mu=10^{3} \mathrm{~cm}^{2} . \mathrm{V}^{-1} \mathrm{~s}^{-1}, \quad \tau=10^{-6} \mathrm{~s}\right)$

The excess minority carriers density increase to a maximum for a certain base depth $\mathrm{x}_{0}$; from $\mathrm{x}=0$ to $\mathrm{x}_{0}$, all the excess minority an cross the junction and participate to the photocurrent. When the depth in the base exceeds $\mathrm{x}_{0}$, the remaining carriers cannot cross the junction. One can note also that the excess minority carrier's density decrease markedly beyond $\mathrm{x}_{0}$.

This behavior could be understood by the fact that incident photons flux is more absorbed near the illuminated surface and this absorption process decrease rapidly in a exponential manner with the depth in the base.

The figure also show that the excess minority carrier's density increase with increasing magnetic field. This behavior is due to the fact that for increasing magnetic field, the diffusion process trough the base is lowered; excess minority carriers cannot cross the junction (as they do without magnetic field) so that they are stored in the base. This lead to an increase of the carrier concentration in the base of solar cell.

This increase of the excess minority carriers is accompanied by a reduction of the space charge region width, confirming that it is difficult to carriers to cross the junction with increasing magnetic field.

We now present the photocurrent density. 


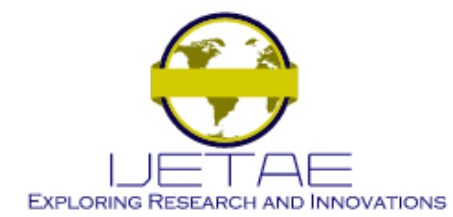

\section{International Journal of Emerging Technology and Advanced Engineering Website: www.ijetae.com (ISSN 2250-2459, ISO 9001:2008 Certified Journal, Volume 11, Issue 02, February 2021)}

\section{Photocurrent density}

Figure 5 present the photocurrent density profile versus junction recombination velocity for various magnetic fields.

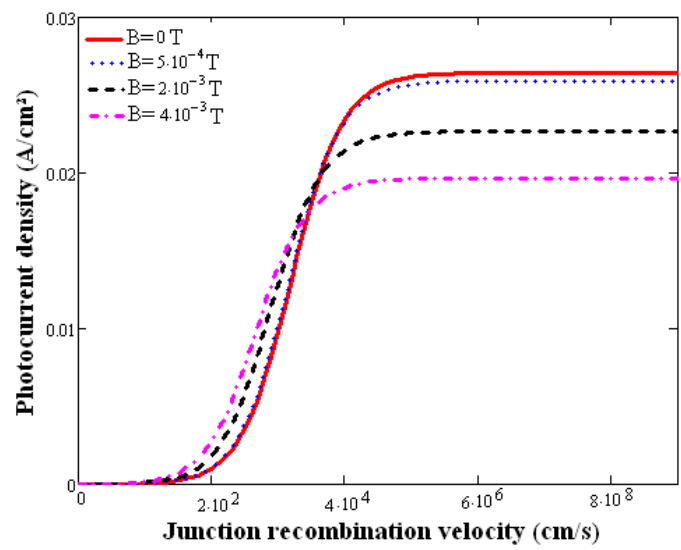

Figure 5: Photocurrent density profile versus junction recombination velocity for various magnetic fields $\left(D=26 \mathrm{~cm}^{2} / \mathrm{s}\right.$, $\mu=10^{3} \mathrm{~cm}^{2} . V^{-1} \mathrm{~s}^{-1}, \tau=10^{-6} \mathrm{~s}$.

The photocurrent density increased with junction recombination velocity; given that junction recombination velocity traduce the excess minority carriers flux trough the junction, and increased flux trough the junction will lead to more carriers collected and thus an increase of the photocurrent density.

Applying a magnetic field to the solar cell near the short circuit (high Sf values) lead to a decrease of the photocurrent density as we can see on the figure above. Effectively, we proved that for increasing magnetic field, carriers are stored in the base because of lower diffusion process; this lead to a decrease of collected carried, that this, a decrease of the photocurrent density. From the open circuit (very low Sf) to the beginning of the short circuit, the observed behavior of the photocurrent density is inverted. This can be explained by the fact that near open circuit, excess minority carriers are already stored near the junction; applying the magnetic field help them to cross the junction that is why the photocurrent density increases a little.

Concept of junction recombination velocity inducing the short circuit ( $S f s c$ )

The short-circuit condition is a situation of total passage towards the emitter of all the electrons photo-generated in the base and crossing the junction. The profile of the photocurrent density as a function of the junction recombination velocity shows that the short-circuit situation is initiated from a characteristic junction recombination velocity Sfsc [25-27].
For such a situation, no charge carrier is stored at the junction and the photocurrent density is maximum and tends asymptotically towards a constant value which is the short-circuit current. This fact can be explained mathematically by the following equation:

$$
\frac{\partial J_{p h}}{\partial S_{f}}=0
$$

In other words, the general expression of the shortcircuit current density is:

$$
\boldsymbol{J}_{S c}=\lim _{S f \rightarrow \infty} \boldsymbol{J}_{p h}
$$

The value of the junction recombination velocity initiating the short-circuit will be deduced from the following equation :

$$
J_{p h}\left(S f_{S c}\right)-J_{S c}=0
$$

The junction recombination velocity gives an intersection. The projection of this point of intersection on the ordinate axis gives the exact value of the short-circuit photocurrent density. However, this technic to determine the short circuit photocurrent density has some limits. Particularly, for the recombination velocities to the junction inferior to the ones initiating the short-circuit situation, this technic is not usable. Its validity domain is defined for recombination velocities superior or equal to a reference velocity and in our case equal to $4,5 \cdot 10^{4,5} \mathrm{~cm} / \mathrm{s}$.

Table 1 presents different Sfsc values corresponding to various magnetic fields.

Table 1:

junction recombination velocity inducing the open circuit for various magnetic fields.

\begin{tabular}{|c|c|c|}
\hline $\mathbf{B}(\mathbf{T})$ & $\mathbf{J s c}\left(\mathbf{A} / \mathbf{c m}^{2}\right)$ & Sfsc $(\mathbf{c m} / \mathbf{s})$ \\
\hline 0 & 0,026429 & $1,197.10^{6}$ \\
\hline $5 \times 10^{-4}$ & 0,025893 & $6,5.10^{5}$ \\
\hline $2 \times 10^{-3}$ & 0,022589 & $2,479.10^{5}$ \\
\hline $4 \times 10^{-3}$ & 0,019643 & $1,461.10^{5}$ \\
\hline
\end{tabular}

The table shows that the recombination inducing the short circuit decrease with the magnetic field; that is, when we apply the magnetic field to the solar cell, the short circuit happens more rapidly than without magnetic field. This phenomenon becomes more marked for increasing magnetic field. 


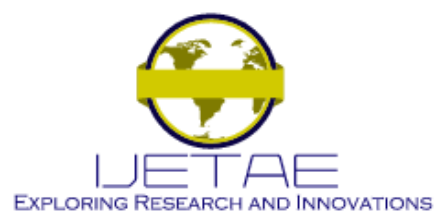

International Journal of Emerging Technology and Advanced Engineering

Website: www.ijetae.com (ISSN 2250-2459, ISO 9001:2008 Certified Journal, Volume 11, Issue 02, February 2021)

\section{Photovoltage}

We illustrate on figure 7 profile of the photovoltage versus junction recombination velocity for various magnetic fields.

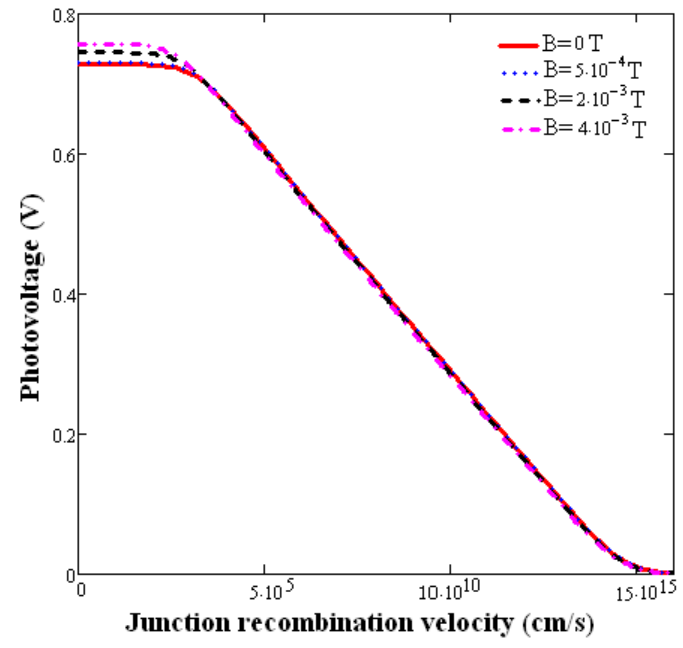

Figure 7 : Photovoltage versus junction recombination velocity for various magnetic fields $\left(D=26 \mathrm{~cm}^{2} / \mathrm{s}, \mu=10^{3} \mathrm{~cm}^{2} \cdot \mathrm{V}^{-1} \mathrm{~s}^{-1}, \tau=10^{-6} \mathrm{~s}\right)$

One can see that the photovoltage decrease with increasing junction recombination velocity. Given that the junction recombination velocity traduces the flow of carriers through the junction, for low Sf value carriers do not cross the junction; they are stored in the base and it is this charge storage that increases the photovoltage[28].

We note also that near open circuit magnetic field increases the open circuit voltage. This can be explained by the fact that with increasing magnetic field, the flow of carriers crossing the junction is lowered because of the incurved path of the carrier leading to an increase of carrier's concentration in the base of the cell thus increasing the photovoltage.

For higher $\mathrm{Sf}$ values the magnetic field effect is neglectable.

Concept of junction recombination velocity limiting the open circuit (Sfoc)

For low values of the junction recombination velocity, the photovoltaic voltage is maximum and constant. The excess minority charge carriers are stored at the junction giving a maximum density of minority charge carriers. This is an open circuit situation where the voltage is maximum while the current is almost zero [26, 27, 28]. This open circuit situation can be explained mathematically by the following equation:

$$
\frac{\partial V_{p h}}{\partial S_{f}}=0
$$

In other words, the general expression of the open circuit phototension density is given by the following relation :

$$
V_{O c}=\lim _{S f \rightarrow 0} V_{p h}
$$

Thus, the value of the junction recombination velocity limiting the open circuit voltage will be deduced from the following equation:

$$
V_{p h}\left(S f_{O c}\right)-V_{O c}=0
$$

Figure 8 shows a technique for determining the junction recombination velocity limiting the open circuit situation Sfoc. In the example below, this velocity is equal to $2,9.10^{2,9} \mathrm{~cm} / \mathrm{s}$.

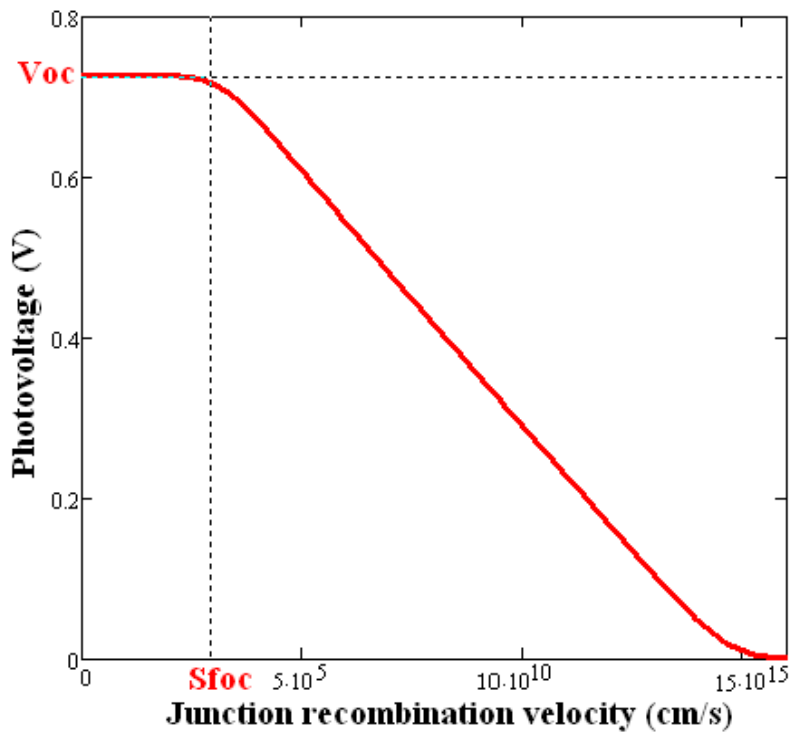

Figure 8: Concept of junction recombination velocity limiting the open circuit (Sfoc)

We proceed in the same way as for determination the junction recombination velocity initiating the short circuit but this technique also has limits. Particularly, for some recombination velocities to the junction superior to the ones limiting the open circuit, this technic is not usable. Its validity domain is defined for recombination velocities inferior or equal to a $2,9.10^{2,9} \mathrm{~cm} / \mathrm{s}$ in our case.

Based on this figure, we determined the Sfoc value for various magnetic fields and the results are presented on the table 2 . 


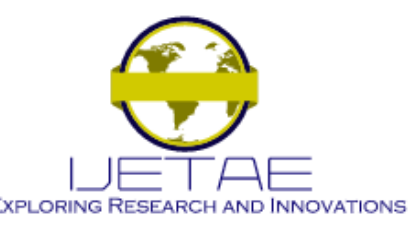

International Journal of Emerging Technology and Advanced Engineering Website: www.ijetae.com (ISSN 2250-2459, ISO 9001:2008 Certified Journal, Volume 11, Issue 02, February 2021)

junction recombination velocity limiting the open circuit for various magnetic fields.

\begin{tabular}{|c|c|c|}
\hline $\mathbf{B}(\mathbf{T})$ & $\mathbf{V c o}(\mathbf{V})$ & $\mathbf{S f c o}(\mathbf{c m} / \mathbf{s})$ \\
\hline 0 & 0,72745 & $1,118.10^{3}$ \\
\hline $5 \times 10^{-4}$ & 0,72745 & $1,118.10^{3}$ \\
\hline $2 \times 10^{-3}$ & 0,74314 & 324,892 \\
\hline $4 \times 10^{-3}$ & 0,75686 & 143,586 \\
\hline
\end{tabular}

This table shows that Sfoc values decrease with the magnetic field.

This means that for increasing magnetic field, the open circuit state terminates more rapidly than that of lower magnetic field, but the open circuit voltage still increase with magnetic field.

\section{CONCLUSION}

A theoretical study for the determination of the recombination speeds at the junction initiating the shortcircuit (Sfsc) and limiting the open circuit (Sfoc) of a silicon solar cell under a magnetic field in static mode was presented. Electrical parameters such as photocurrent density and phototension have been determined. It is noted that the photocurrent increases with the speed of junction recombination up to the maximum value from which it becomes constant. In contrast, the phototension is maximum for low values of the junction recombination velocity and almost zero for high speeds. The operation in a short-circuit situation of the photovoltaic cell corresponds to large values of Sfsc where the current is maximum and constant. The operation of the solar cell in open circuit conditions where the density of the carriers is maximum (maximum phototension) and the zero current is characterized by low values of the junction recombination velocity Sfoc. A technique for determining the junction recombination velocities triggering the short-circuit situation and limiting the open circuit and their domains of validity have also been demonstrated in this study.

\section{Acknowledgements}

One of us, Péné .A. D is very grateful to ANSOLE (African Network for Solar Energy) and ICTP (International Centre for Theoretical Physics) for financial support with the ICTP-ANSOLE fellowship through the INEX Program

\section{REFERENCES}

[1] S. Mbodji, A. S. Maiga, M. Dieng, A. Wereme and G. Sissoko; Renoval charge technic applied to a bifacial solar cell under constant magnetic field; Global Journal of Pure and Applied Sciences VOL 16, NO. 4 2010: 469- 477 http://www.globaljournalseries.com

[2] Barro FI, Sane M and Zouma B (2015) On the Capacitance of Crystalline Silicon Solar Cells in Steady State. Turkish Journal of Physics, 39, 122-127.

[3] Kolsi S, Samet H and Amar MB (2010) An Efficiency Optimization of a Polysi licon Photovoltaic Module Using a 2-D Analytical and a Two-Diode i-v Model for an Illuminated Solar Cell. Lebanese Science Journal, 11, 87-104.

[4] Khan F, Singh SN and Husain M (2010) Effect of Illumination Intensity on Cell Parameters of a Silicon Solar Cell. Solar Energy Materials \& Solar Cells, 94, 1473- 1476.

[5] Zerbo I, Zoungrana M, Seré AD, Ouedraogo F, Sam R, Zouma B and Zougmoré F (2011) Influence d'une onde électromagnétique sur une photopile au silicium sous éclairement multispectral en régime statique. Revue des Energies Renouvelables, 14, 517-532.

[6] Dieye M, Mbodji S, Zoungrana M, Zerbo I, Dieng B and Sissoko G (2015) A 3D Modelling of Solar Cell's Electric Power under Real Operating Point. World Journal of Condensed Matter Physics, 5, 275-283.

[7] Nzonzolo, Lilonga-Boyenga D and Sissoko G (2014) Illumination Level Effects on Macroscopic Parameters of a Bifacial Solar Cell. Energy and Power Engineering, 6, 25-36.

[8] El-Shaer A, Tadros MTY and Khalifa MA (2014) Effect of Light Intensity and Temperature on Crystalline Silicon Solar Modules Parameters. International Journal of Emerging Technology and Advanced Engineering, 4, 311-318.

[9] Péné AD, Bitjoka L, Barro FI, Nkeng GE, Kapseu C, Sissoko G, (2013) Influence of magnetic field on the electrical parameter of a bifacial silicon solar cell front side illuminated by a multispectral light under steady state, International Journal of Emerging Technology and Advanced Engineering, Volume 3, Issue 9.

[10] Zoungrana M, Zerbo I, Ouédraogo F, Zouma B and Zougmoré F (2012) 3D Modelling of Magnetic Field and Light Concentration Effects on a Bifacial Silicon Solar Cell Illuminated by Its Rear Side. IOP Conf. Series: Materials Science and En gineering, 29, 012020.

[11] Mbodji S, Maiga AS, Dieng M, Wereme A and Sissoko G (2010) Renoval charge technic applied to a bifacial solar cell under constant magnetic field; Global Journal of Pure and Applied Sciences VOL 16, NO. 4: 469- 477 http://www.globaljournalseries.com

[12] Zouma B, Maiga AS, Dieng M, Zougmore F, Sissoko G (2009) 3D Approach of spectral response for a bifacial silicon solar cell under a constant magnetic field; Global Journal of Pure and Applied Sciences, Vol.15, $\mathrm{N}^{\circ} 1$, pp.117-124.

[13] Samb ML, Zoungrana M, Sam R, Dione MM, Deme MM, Sissoko G (2010) Etude en modélisation à 3-D d'une photopile au silicium en régime statique placée dans un champ magnétique et sous éclairement multispectral : détermination des paramètres électriques. J. Sci. Vol 10, $\mathrm{N}^{\circ}$ 4. 23-38

[14] Toure F, Zoungrana M, Sam R, Diop MTD, Barro FI, Sissoko G (2010) Effetdu champ magnétique sur le rendement de la capacité d'une photopile monofaciale au silicium par le modèle de l'extension de la zone de charge d'espace. J. Sci. Vol 10, $\mathrm{N}^{\circ} 4$. 1622 


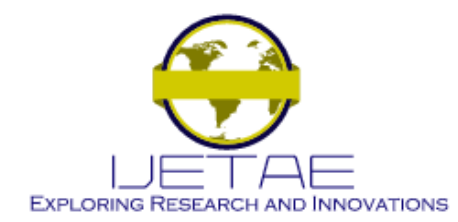

International Journal of Emerging Technology and Advanced Engineering Website: www.ijetae.com (ISSN 2250-2459, ISO 9001:2008 Certified Journal, Volume 11, Issue 02, February 2021)

[15] Ricaud A. (1997) Photopiles Solaires, Presses Polytechniques et Universitaires Romandes

[16] Samb M. L., Sarr S, Mbodji S, Gueye S, Dieng M and Sissoko G (2009) Etude en modélisation à 3-D d'une photopile au silicium en régime statique sous éclairement multispectrale : détermination des paramètres électriques. J. Sci.Vol. 9, N $436-50$.

[17] Combari DU, Zerbo I, Zoungrana M, Ramde E and Bathiebo DJ (2017) Modelling Study of Magnetic Field Effect on the Performance of a Silicon Photovoltaic Module. Energy and Power Engineering, 9, 419-429

[18] Mbodji S, Zoungrana M Zerbo I, Dieng B. and Sissoko G. (2015) Modelling Study of Magnetic Field's Effects on Solar Cell's Transient Decay. World Journal of Condensed Matter Physics, 5, 284-293.

[19] Deme MM, Mbodji S, Ndoye S, Thiam A, Dieng A And Sissoko G (2010) Influence of illumination incidence angle, grain size and grain boundary recombination velocity on the facial solar cell diffusion capacitance »; Revues des Energies Renouvelables; Vol. 13, No.1, , pp 109-121

[20] Daniel LM, Jeong-Mo H, Robert B (1988) Campbell. IEEE Transactions on Electron Devices, vol. ED-35, No.1, pp.70 - 78

[21] Mohammad S.N (1987) An alternative method for the performance analysis of silicon solar cells, J. Appl. Phys. 61 (2), pp 767 - 777

[22] Dieng A, Thiam N, Thiam A, Maiga AS and Sissoko G (2011) Magnetic Field Effect on the Electrical Parameters of a Polycrystalline Silicon Solar Cell; Research Journal of Applied Science, Engineering and Technology 3(7): 602-611
[23] Madougou S, Made F, Boukary MS, and Sissoko G (2007) I-V Characteristics for Bifacial Silicon Solar Cell studied under a Magnetic field; Advanced Materials Research Vols. 18-19 pp. 303312 online at http://www.scientific.net (C) (2007) Trans Tech Publications, Switzerland - ISSN : 1022-6680 and ISBN: 0-87849450-2d

[24] Diallo HL, Maiga AS, Wereme A, Sissoko G (2008) New approach of both junction and back surface recombination velocity in a $3 \mathrm{D}$ modelling study of a polycrystalline silicon solar cell; Eur. Phys. J. Appl. Phys. 42, 203-211

[25] Sissoko G, Museruka C, Corréa A, Gaye I and. Ndiaye AL (1996) Light spectral effect on recombination parameters of silicon solar cell. Renewable Energy. 3: 1487-1490

[26] Sahin, G., Kerimli, G (2018) Determination of the Junction Recombination Velocity Initiating the Short Circuit Situation Sfsc of a Bifacial Silicon Solar Cell Irradiated Under Magnetic Field in Dynamic Frequency Regime. Silicon 10, 1661-1665

[27] ly I, Ndiaye M, Wade M, Ndeye T, Sega G and Sissoko G (2013) Concept of Recombination Velocity Sfcc at the Junction of a Bifacial Silicon Solar Cell, in Steady State, Initiating the ShortCircuit Condition, Research Journal of Applied Science, Engineering and Technology Vol. 5 , (1): 203-208

[28] Sahin G (2016) "Effect of Wavelength on the Photocurrent and Photovoltage of Vertical Parallel Silicon Solar Cells under Steady State Condition", Journal of Basic and Applied Physics, Vol. 5 Iss. 1, PP. 30-39

[29] Diouf MS, Gaye I, Thiam A, Fall MFM, Ly I, Sissoko G (2014) Junction Recombination Velocity Induced Open Circuit Voltage For A Silicon Solar Cell Under External Electric Field, Current Trends in Technology and Science, ISSN: 2279- 0535. Volume: 3, Issue: 5. 